\title{
Phosphorus, calcium, and magnesium contents of pasture and their effect on body condition scores and body mass of communal cattle depending on natural pasture of Mogosane Village, of the North-West Province, South Africa
}

\author{
B. G. Mokolopi ${ }^{1}$ \\ Received: 19 October 2018 / Accepted: 29 April 2019 / Published online: 4 June 2019 \\ (C) The Author(s) 2019
}

\begin{abstract}
This research was conducted to determine the effects of phosphorus $(\mathrm{P})$, calcium $(\mathrm{Ca})$, and magnesium $(\mathrm{Mg})$ content in pasture with body weight and body condition scores in cattle depending entirely on natural grazing. The work was done in 2006 in Mogosane Village of North-West Province, South Africa, and it was conducted from March 2006 to March 2007, with the annual rainfall of $384.38 \mathrm{~mm}$ maximum. A total of 25 growing mixed breed cattle aged between 6 months and 2 years old were selected randomly from a herd feeding exclusively on communal grazing. Animals were depending on natural pasture, with no supplements given. Records of body mass (BM) and body condition score (BCS) were recorded from a diverse range of animals in order to include as many different body masses and body condition scores as possible. Mean BM and BCS values are reported but there were no significant $(P>0.05)$ differences between months. Possible reasons are given in the "Results and Discussion" section. The focus of the research reported here was on the changes in the $\mathrm{P}, \mathrm{Ca}$, and $\mathrm{Mg}$ concentrations of pasture. Pasture samples were collected once a month for analysis to determine the contents of $\mathrm{P}, \mathrm{Ca}$, and $\mathrm{Mg}$. Mineral concentrations in the pasture increased significantly $(P<0.05)$ with rainfall in January 2007, February 2007, and March 2007, and in January 2007 and February 2007 , the mean values of BCS (3.90) and BM (444.05 kg) increased. After the good rains in March 2006 and April 2006, there were significant $(P<0.05)$ decreases in grass $\mathrm{P}$ and $\mathrm{Mg}$ in the following dry months along with decreases in BCS and BM. There were subsequent significant $(P<0.05)$ increases in grass $\mathrm{P}$ and $\mathrm{Mg}$ following rains in August 2006 through January 2007. Grass Ca followed a much different pattern compared with that of $\mathrm{P}$ and $\mathrm{Mg}$ with significant $(P<0.05)$ increases after periods of little or no rainfall. Mineral concentrations $(\mathrm{P}, \mathrm{Ca}$, and $\mathrm{Mg})$ of grass in this research were significantly $(P<0.05)$ influenced by the rainfall making it imperative that mineral supplementation be given to animals in the dry periods.
\end{abstract}

Keywords Pasture minerals $\cdot$ Communal cattle $\cdot$ Natural pasture $\cdot$ Body condition score $\cdot$ Body weight

\section{Introduction}

Livestock in arid areas of Africa utilize crop residues which have low nutritive value, and natural pasture which depends on fluctuating rainfall (Alshafei et al. 2016). Poor nutrition especially during the dry season affects productivity of

\section{B. G. Mokolopi}

kgobebg@unisa.ac.za

1 Department of Agriculture and Animal Health, College of Agriculture and Environmental Sciences, University of South Africa, Science Campus, Private Bag X6, Florida, Johannesburg 1710, South Africa livestock and results in economic losses to the livestock owners, and according to Solomon and Mlambo (2017), livestock, particularly cattle and goats, play an important socioeconomic role in South Africa. Ruminant animal production is a means of sustainability to people living in rural, peri-urban, and urban areas (Ogunbosoye et al. 2015).

Minerals are dietary essentials for optimal growth, physiologic functions, and productivity in animals (Herdt and Hoff 2011) and are essential for maintaining livestock growth, reproduction, and health (Jones and Tracy 2013). The performance and health of grazing ruminants are dependent on the adequacy and availability of essential mineral elements from pastures and soil (Islam et al. 2003), and according to Gao et al. (2016), herbage minerals affect the performance of 
grazing cattle. In a given pasture, mineral levels vary from species to species, and mineral imbalances occur in different areas of the world (Fardous et al. 2010). Therefore, mineral deficiencies may affect the production of grazing livestock at pasture in most of the regions of the world, which include those of the major elements $\mathrm{Ca}, \mathrm{P}, \mathrm{Mg}, \mathrm{Na}$, and $\mathrm{S}$, and the trace elements $\mathrm{Co}, \mathrm{Cu}, \mathrm{I}, \mathrm{Mn}, \mathrm{Se}$, and $\mathrm{Zn}$ (Goswami et al. 2005) and can compromise cattle health and, consequently, the income to the farmers (Dermauw et al. 2013). Although hand-plucked forage pasture samples are not representative of what an animal actually grazes, they can serve as a vital diagnostic aid when sample collection by esophageal fistula is not convenient. Undoubtedly, forage analysis is a potential indicator of mineral status for ruminants as compared with that of soil (Khan et al. 2009).

Most animal and dairy scientists acknowledge successfully manipulating body condition scores (BCS) as an important management factor, influencing animal health, milk production, and reproduction in the modern dairy cow (Buckley et al. 2003). They are subjective, visual, or tactile evaluations of the amount of subcutaneous fat on a cow (Waltner et al. 1993). According to Roche et al. (2004), managing body reserves is critical for successful cow management and requires an accurate assessment of a cow's condition, and according to them, body mass (BM) alone was not a good indicator of body reserves, as cows of a specific weight may be tall and thin or short and fat. Furthermore, scoring body condition and assessing changes in the body condition of dairy cattle have become strategic tools in both farm management and research. Changes in BCS as measured over several weeks provide useful information about the cow's current nutrient intake relative to its requirements, and allow feeding decisions to be made effectively (Roche et al. 2007). Low BCS is used as an indirect indicator of energy balance status (Berry et al. 2007), and the public perception is that thin cows are welfare-compromised. However, no comprehensive studies on the mineral status of natural pastures on BCS and BW of cattle in communal grazing of Mogosane village of the North-West Province have been conducted. Furthermore, an understanding of how BCS and BM change with time and the content of minerals the animals consumed, and how they influence production and health, could potentially help communal farmers to take care of their animals, by at least supplementing them especially during dry periods when mineral status of the pasture is limiting. The objective of the study was, therefore, to monitor changes in grass $\mathrm{P}, \mathrm{Ca}$, and $\mathrm{Mg}$ related to season and rainfall, and to monitor BCS and BM of cattle subjected to natural grazing. Little is known about how pasture $\mathrm{P}, \mathrm{Ca}$, and $\mathrm{Mg}$ contents are affected by rainfall and how they affect BCS and BM of cattle depending only on natural grazing.
I therefore hypothesized the following:

i. Decreased rainfall will decrease $\mathrm{P}, \mathrm{Ca}$, and $\mathrm{Mg}$ contents of grass in pastures.

ii. Increased rainfall will increase $\mathrm{P}, \mathrm{Ca}$, and $\mathrm{Mg}$ contents of grass in pastures.

iii. Pasture with more $\mathrm{P}, \mathrm{Ca}$, and $\mathrm{Mg}$ contents will increase $\mathrm{BCS}$ and BM measured.

iv. Pasture with less $\mathrm{P}, \mathrm{Ca}$, and $\mathrm{Mg}$ contents will lower the levels BCS and BM recorded.

\section{Materials and methods}

\section{Experimental procedures}

This research was a part of the research project carried out for a Ph.D. degree by the senior author awarded in 2009 by North-West University, Mafikeng Campus. The work was done in 2006 in Mogosane Village in the Molopo District of North-West Province, South Africa, and it was conducted from March 2006 to March 2007, with an average annual rainfall of $384.38 \mathrm{~mm}$.

Twenty-five mix breed cattle between the ages of 6 months and 2 years were randomly selected from among a group of animals feeding exclusively on communal grazing in Mogosane Village in the Molopo District of North-West Province and were used to determine how pasture $\mathrm{P}, \mathrm{Ca}$, and $\mathrm{Mg}$ contents affect BCS and BM of cattle depending only on natural grazing. During this project, the animals were allowed to graze only on natural pastures; no supplements were given. Pasture samples were directly collected from the veld once a month for 12 months as described by Mokolopi and Beighle (2006). They were cut using a stainless-steel knife and placed in clean cloth bags at the site (Khan et al. 2006).

Animals were ear-tagged. Records of body mass (BM) and body condition score (BCS) were also recorded with the assistance of two experienced evaluators, using 1-5 scale, as described by Wildman et al. (1982) that the method of BCS is based on a visual and tactile appraisal of body fat reserves in the back and pelvic regions. All the samples were collected once a month for a complete year to include the summer, autumn, winter, and spring seasons. Rainfall data was provided by the Department of Geography, North-West University, for the whole survey period.

\section{Laboratory procedures}

All laboratory equipment used in the digestion and analysis of grass samples were soaked in $36 \%$ hydrochloric acid $(\mathrm{HCl})$ overnight. They were then rinsed with distilled water 3 times and were dried in a hot air oven for $16 \mathrm{~h}$ at $106{ }^{\circ} \mathrm{C}$. After 
drying, crucibles were allowed to cool in a desiccator for $6 \mathrm{~h}$ when they were then weighed to determine the empty weight. Pasture samples were then digested as described by Beighle et al. (1990), were analyzed for P through the FASPac II Version R2MI Auto-Analyzer (Astoria Pacific International 1992-2005), and were analyzed according to the method of Fiske and Subarrow (1925). Pasture samples were analyzed for $\mathrm{Ca}$ and $\mathrm{Mg}$ through an Atomic Absorption Spectrometer (The Analyst 700 model, 110 Bridgeport Avenue Shelton, CT 06484-4794, USA) and were analyzed as described by Trudeau and Freier (1967).

\section{Statistical analysis}

The effect of $\mathrm{P}, \mathrm{Ca}$, and $\mathrm{Mg}$ contents of pasture on $\mathrm{BM}$ and BCS of communal cattle depending on natural pasture was analyzed using general linear model (GLM) procedures of the statistical analyses system (SAS 2010). The statistical model used was as follows:

$\mathrm{Y}_{\mathrm{ijk}}=\mathrm{i}+\mathrm{T}_{1}+{ }^{\text {" }}{ }_{\mathrm{ijk}}$

where

$Y_{\mathrm{ijk}}$ the overall observation (BM and BCS)

$i \quad$ population means

$T_{1} \quad$ Effect of pasture minerals ( $\mathrm{P}, \mathrm{Ca}$, and $\mathrm{Mg}$ )

" ${ }_{\mathrm{ijk}}$ Residual effect

Where there was a significant $t$ test $(P<0.05)$, Duncan multiple range was used to test the significance of differences between means.

\section{Results and discussion}

There were significant $(P<0.05)$ decreases in grass $\mathrm{P}$ in the dry period, June 2006 to August $2006(0.34 \mathrm{mg} / \mathrm{g}$ in June 2006, $0.33 \mathrm{mg} / \mathrm{g}$ in July 2006, and $0.35 \mathrm{mg} / \mathrm{g}$ in August 2006) compared with March 2006 (2.4 mg/g dry weight), April (1.74 mg/g dry weight), and May $(1.17 \mathrm{mg} / \mathrm{g}$ dry weight) (Table 1$)$ following the rainfall of $111.2 \mathrm{~mm}$ in March 2006 and $93.6 \mathrm{~mm}$ in April 2006. It is worth noting that even a moderate rainfall of $19.3 \mathrm{~mm}$ in August 2006 was responsible for a significant $(P<0.05)$ increase in grass $\mathrm{P}$ in September $(1.35 \mathrm{mg} / \mathrm{g}$ dry weight) and October $(1.01 \mathrm{mg} / \mathrm{g}$ dry weight) compared with $0.34 \mathrm{mg} / \mathrm{g}$ in June 2006 , $0.33 \mathrm{mg} / \mathrm{g}$ in July 2006, and $0.35 \mathrm{mg} / \mathrm{g}$ in August 2006 (Table 1). These results indicate that the $\mathrm{P}$ content in grass can increase significantly $(P<0.05)$ in response to moderate rainfall. With only $19.3 \mathrm{~mm}$ of rainfall in August 2006, the $\mathrm{P}$ concentration in grass increased from
$0.35 \mathrm{mg} / \mathrm{g}$ dry weight in August 2006 to $1.35 \mathrm{mg} / \mathrm{g}$ dry weight in September 2006, and again with moderate rainfall of $1 \mathrm{~mm}$ in September, $14.1 \mathrm{~mm}$ in Oct 2006, $33.8 \mathrm{~mm}$ in November 2006, $60.8 \mathrm{~mm}$ in January 2007, and $9.7 \mathrm{~mm}$ in February 2007, the P content of the grass in September, October, November, January, February, and March remained significantly $(P<0.05)$ above that of the dry period of June 2006, July 2006, and August 2006.

Grass Ca concentrations did not follow the pattern of P. Following 2 months of good rainfall in March 2006 (111.3 mm) and April 2006 (93.6), there were no significant $(P<0.05)$ increases in the concentration of $\mathrm{Ca}$ in the grass in April 2006, May 2006, June 2006, or July 2006, and in June 2006 and in July 2006, there were even significant $(P<0.05)$ decreases in grass Ca $(7.29 \mathrm{mg} / \mathrm{g}$ and $7.01 \mathrm{mg} / \mathrm{g}$ dry weight). In August 2007, there was a significant $(P<0.05)$ increase in grass $\mathrm{Ca}(8.80 \mathrm{mg} / \mathrm{g})$ despite the fact that there was no rainfall in July 2006 (Table 1). The difference in the response of grass $\mathrm{P}$ and $\mathrm{Ca}$ to the rainfall is seen in the results in June 2006, July 2006, and August 2006. Grass P was significantly $(P<0.05)$ lower in June 2006, July 2006, and August 2006 compared with those months before and after, while grass Ca was significantly $(P<0.05)$ higher in August 2006 compared with June 2006 and July 2006 despite the fact that there was no rainfall in July 2006. In addition, there were no significant differences in grass $\mathrm{P}$ during the months of September 2006 through March 2007, but grass Ca showed significant $(P<0.05)$ differences during those same months ranging from a high level of $9.01 \mathrm{mg} / \mathrm{g}$ dry weight in September 2006 to a low level of $6.31 \mathrm{mg} / \mathrm{g}$ dry weight in November 2006 and then another high level in March 2007 of $8.99 \mathrm{mg} / \mathrm{g}$ dry weight even when there were rainfalls of $33.8 \mathrm{~mm}$ in November 2006 and $60.8 \mathrm{~mm}$ in January 2007. Grass Ca concentrations were not as dependent on rainfall as were grass $\mathrm{P}$ concentrations, because there was a significant $(P<0.05)$ increase in grass Ca in August 2006 compared with July 2006 after no rainfall in July 2006, and there was a significant $(P<0.05)$ increase in grass $\mathrm{Ca}$ in March 2007 compared with February 2007 despite a very low rainfall $(9.7 \mathrm{~mm})$ in February 2007 (Table 1). For animals that depend on grass as their only source of minerals, this has implications for the animal's ability to maintain a normal Ca:P ratio with much different responses of grass $\mathrm{Ca}$ and $\mathrm{P}$ to rainfall as seen in August 2006 where there was significantly $(P<0.05)$ less grass $\mathrm{P}$ but significantly $(P<0.05)$ more grass $\mathrm{Ca}$.

Grass $\mathrm{Mg}$ values in response to rainfall were similar to grass $\mathrm{P}$ concentrations except that the grass $\mathrm{Mg}$ values responded to the decrease in rainfall in May 2006 faster than did the grass $\mathrm{P}$. Grass $\mathrm{P}$ was significantly $(P<0.05)$ less in June 2006, but grass Mg was not significantly lower in May, June, and July 2006, and grass Mg remained significantly lower through September 2006 while grass P was significantly 
higher in September 2006. This would indicate that the grass was able to increase its $\mathrm{P}$ concentration quicker in response to rainfall than it was to increase its $\mathrm{Mg}$ concentration. This was also the case in September 2006 through March 2007 when the grass was able to maintain consistent concentrations of $\mathrm{P}$ (Table 1), but the grass was not able to maintain consistent values for $\mathrm{Mg}$ with significantly higher values in October $2006(0.31 \mathrm{mg} / \mathrm{g})$ and November $2006(0.30 \mathrm{mg} / \mathrm{g})$ compared with August 2006 and September 2006, but an even significantly higher value in January $2007(0.35 \mathrm{mg} / \mathrm{g})$ followed by a significantly lower value in February 2007 (0.28 mg/g) and then a significantly higher value in March $2007(0.33 \mathrm{mg} / \mathrm{g})$ (Table 1). This has very important implications for the prevention of conditions such as grass tetany in animals maintained only on grass as their only source of $\mathrm{Mg}$.

There were no significant $(P>0.05)$ differences in the $\mathrm{BCS}$ or in the $\mathrm{BM}$ throughout the experiment period despite the significant $(P<0.05)$ differences seen in $\mathrm{P}, \mathrm{Ca}$, and $\mathrm{Mg}$ values during the same period in response to the different rainfall patterns. This could be explained in part by the fact that the pastures were overgrazed and so the grass was always in short supply and the animals were never able to consume large amounts of grass over a long period of time and gain weight. What growth of grass there was from the rains was quickly consumed by large numbers of animals communally grazed in the area. Although they were not significant $(P>0.05)$, the BCS of 3.71 and the BM of $377.05 \mathrm{~kg}$ were both higher in May 2006 than those in April 2006 (3.57 and $366.38 \mathrm{~kg}$ ) in response to $111.2 \mathrm{~mm}$ rainfall in March 2006 and $93.6 \mathrm{~mm}$ in April 2006.

Ruminants are not able to maintain or store large amounts of $\mathrm{Mg}$ in the body and rely on a constant source of $\mathrm{Mg}$ in the diet for prevention of conditions such as grass tetany (Goff 2008). The results of this research bring attention to the fact that communally grazed animals require mineral supplementation, especially $\mathrm{P}$ and $\mathrm{Mg}$ for the prevention of mineral deficiencies.

Acknowledgements The author would like to thank the Animal Health Department (North West University) for their laboratory equipment and Animal Health Postgraduates students for assisting in the collection of samples. Great thanks to Dr. Mulugeta for his assistance in statistical analysis, and Canon Collins Trust for their financial support. Great acknowledgement is given to Mokolopi's family for providing the research animals and Mr. Dockey Mokolopi who took care of research animals.

\section{Compliance with ethical standards}

The research animals were handled under the supervision of the University Veterinarian from the Animal Health Department. This survey was part of a Ph.D. study which was approved by a research ethics committee at the institutional level. Therefore, the welfare and handling of the research animals were properly followed.

Conflict of interest The authors declare that they have no conflict of interest. 
Open Access This article is distributed under the terms of the Creative Commons Attribution 4.0 International License (http:// creativecommons.org/licenses/by/4.0/), which permits unrestricted use, distribution, and reproduction in any medium, provided you give appropriate credit to the original author(s) and the source, provide a link to the Creative Commons license, and indicate if changes were made.

\section{References}

Alshafei, N. K., Elshafie, A. E. and Nour, A., 2016. Guiera senegalensis (Gs) leaves as source of proteins and minerals for small ruminants in dry areas of Western Sudan. International Journal of Applied and Pure Science and Agriculture (IJAPSA) 2:233-239.

Beighle, D. E, Tucker, W. B. and Hemken, R. W., 1990. Interactions of dietary cation-anion balance and phosphorus: effects on blood, bone and faecal phosphorus concentration in dairy calves. Journal of the South African Veterinary Association, 61: 5-8.

Berry, D. P., Lee, J. M., Macdonald, K. A., Stafford, K., Matthews, L. and Roche, J. R., 2007. Associations among body condition score, body weight, somatic cell count and clinical mastitis in seasonally calving dairy cattle. J. Dairy Sci. 90:637-648.

Buckley, F., Sullivan, K. O., Mee, J. F., Evans R. D. and Dillon P., 2003. Relationships among milk yield, body condition, cow weight and reproduction in spring- calved Holstein-Friesians. J. Dairy Sci 86: 2308-2319.

Dermauw, V., Yisehak, K., Belay, D., Van Hecke, T., Du Laing, G., Duchateau, L. and Janssens, G. P. J., 2013. Mineral deficiency status of ranging zebu (Bos indicus) cattle around the Gilgel Gibe catchment, Ethiopia. Trop Anim Health Prod 45:1139-1147.

Fardous, A., Gondal, S., Shah, Z. A., Ahmad, K., Khan, Z. I., Ibrahim, M., Ejaz, A., Ahmad, W., Ullah, S. and Valeem, E. E., 2010. Sodium, potassium and magnesium dynamics in soil-plant- animal continuum. Pak. J. Bot., 42(4): 2411-2421.

Fiske, C. H. and Subarrow, Y., 1925. The colorimetric determination of phosphorus. Journal of Biological Chemistry, 66: 375-400.

Gao, X., Hao, X., Marchbank, D. H., Beck, R., Willms, W. D. and. Zhao M., 2016. Responses of herbage $\mathrm{P}, \mathrm{Ca}, \mathrm{K}$ and $\mathrm{Mg}$ content and $\mathrm{Ca} / \mathrm{P}$ and $\mathrm{K} /(\mathrm{Ca}+\mathrm{Mg})$ ratios to long-term continuous and discontinued cattle grazing on a rough fescue grassland. Grass and Forage Science, 72, 581-589.

Goff, J. P., 2008. The monitoring, prevention, and treatment of milk fever and subclinical hypocalcemia in dairy cows. The Veterinary Journal, 176:50-57

Goswami, T. K., Bhar, R., Jadhav, S. E., Joardar, S. N. and Ram G. C., 2005. Role of dietary zinc as a nutritional immunomodulator. AsianAust. J. Anim. Sci 18:439-452.

Herdt, T.H. and Hoff, B., 2011. The use of blood analysis to evaluate trace mineral status in ruminant livestock. The Veterinary clinics of North America. Food Animal Practice, 27, 255-283.

Islam, M. R., Saha, C. K., Sharker, N. R., Jahilil, M. and Hasanuzzaman, M., 2003. Effect of variety on proportion of botanical fraction and nutritive value of different Napier grass (Pennisetum purpureum) and relationship between botanical fraction and nutritive value. Asian Aust. J. Anim. Sci 16:177-188.

Jones G. B. and Tracy B. F., 2013. Evaluating seasonal variation in mineral concentration of cool-season pasture herbage. Grass and Forage Science, 69, 1-8.

Khan, Z. I., Hussain, A., Ashraf, M. and McDowell, L. R., 2006. Mineral status of soils and forages in southwestern Punjab-Pakistan: microminerals 2006. Asian-Aust. J. Anim. Sci19(8):1139-1147.

Khan, Z. I., Ashraf, M., Ahmad, K., Valeem, E. E. and McDowell, L. R., 2009. Mineral status of forage and its relationship with that of plasma of farm animals in Southern Punjab, Pakistan. Pak. J. Bot, 41(1): 67-72.

Mokolopi, B. G. and Beighle, D. E., 2006. Evaluation of the mineral status of cattle on communal grazing in the North West Province of South Africa. Journal of the South African Veterinary Association, 77: 179-183.

Ogunbosoye, D. O., Tona, G. O. and Otukoya, F. K., 2015. Evaluation of the nutritive value of selected browse plant species in the southern guinea Savannah of Nigeria for feeding to ruminant animals. British Journal of Applied Science \& Technology 7(4): 386-395.

Roche, J. R., Dillon, P. G., Stockdale, C. R., Baumgard, L. H. and VanBaale, M. J., 2004. Relationships among international body condition scoring systems. J. Dairy Sci 87:3076-3079.

Roche, J. R., Berry, D., Plee, J. M., Macdonald, K. A. and Boston, R. C., 2007. Describing the body condition score change between successive calvings: a novel strategy generalizable to diverse cohorts. J. Dairy Sci 90:4378-4396.

SAS, 2010. SAS Users Guide: Statistics. Version 9.3. SAS Institute, Cary, NC, USA.

Solomon, T. and Mlambo, V., 2017. Macro and trace elements of 26 browse species growing in semi-arid grazing lands of Eastern Cape, South Africa. African Journal of Range \& Forage Science 34(4): 209-217.

Trudeau, D. L. and Freier, E. F., 1967. Determination of calcium in urine and serum by atomic absorption spectrophotometer (AAS). Clinic Chemistry, 13: 103-114.

Waltner, S. S., McNamara, J. P. and Hillers, J. K., 1993. Relationships of body condition score to production variables in high producing Holstein dairy cattle. J. Dairy Sci. 76:3410.

Wildman, E. F., Jones, G. M., Wagner, P. E., Boman, R. L., Troutt H. F. and Lesch T. N., 1982. A dairy cow body condition scoring system and its relationship to selected production characteristics. J. Dairy Sci. 65, 495-501.

Publisher's note Springer Nature remains neutral with regard to jurisdictional claims in published maps and institutional affiliations. 